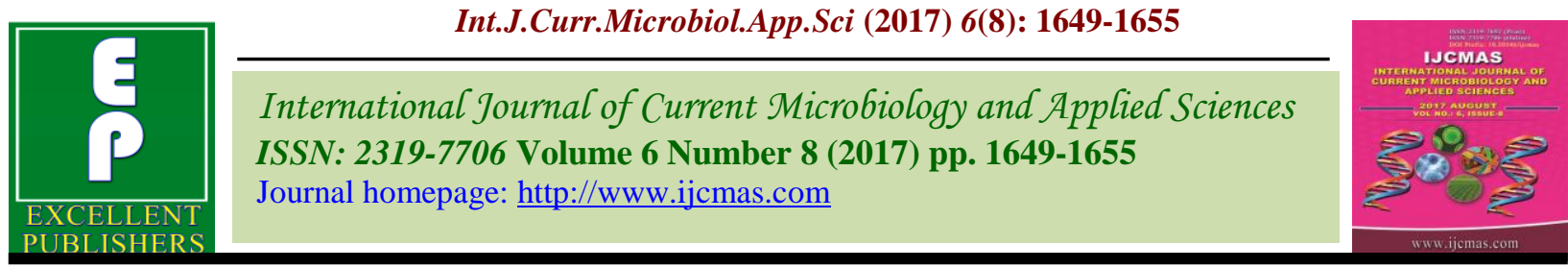

Review Article https://doi.org/10.20546/ijcmas.2017.608.198

\title{
Gametophytic Selection: A Simple Technique for Thermo Tolerance Genotypes Identification in Maize
}

\author{
Ashutosh Singh ${ }^{1}$, Rajen Chowdhury ${ }^{2}$ and Ratan Das ${ }^{3}$ \\ ${ }^{1}$ Department of Plant Biotechnology UAS GKVK Bengaluru, India \\ ${ }^{2}$ Department of Biotechnology, CPMB\&B, Tamil Nadu Agricultural University, India \\ ${ }^{3}$ Department of Horticulture and Post Harvest Technology Visva-Bharati, India \\ *Corresponding author:
}

\section{A B S T R A C T}

\begin{tabular}{|l|}
\hline Ke y w o r d s \\
Thermo tolerance \\
Genotypes, \\
Gametophytic \\
selection.
\end{tabular}

\section{Introduction}

The main goal of any plant breeding program is the improvement of all characteristics that contribute to economic value. These characteristics may be increased yield, ability of tolerant to biotic and abiotic stresses (Fehr 1991). Traditional selection has mainly focused on the sporophytic phase of a plant's life cycle. But sporophytic selection has many limitations. With the improvement of breeding techniques and biotechnological advances, now many options available to plant scientists interested in improving an array of plant responses and characteristics.

In recent time information available from plant genome and many advance techniques are developed a small but growing resurgence of research focused on male gamete selection has developed (McCormick, 2004). The life cycle of angiosperms are consist of two parts (Gametophytic and sporophytic) and it provide opportunity to introduce early selection into breeding program via gametophytic selection (Fig. 1). The most prominent phase of angiosperm life cycle is the sporophytic generation and it develops from zygote followed by the fertilization.

\section{Constrains of sporophytic selection}

Traditional selection has mainly focused on the sporophytic phase of a plant's life cycle. 
But sporophytic selection has many limitations. It is extremely time consuming, labor intensive and can occupy vast quantities of space. Sporophytic selection also requires large population sizes in order to obtain the essential combination of attributes needed to improve a crop.

Many woody perennial species especially have lagged behind in new cultivar development due to larger physical size and long juvenile phases (Hormaza and Herrero, 1996). Sporophytic selection needs to repeat several seasons that increase the cost of selection. The environment changes day by day so it is very difficult to screen the crops at the field.

The life cycle of angiosperms offers the opportunity to introduce early selection into breeding programs via gametophytic selection. The alternation of generations that occurs in angiosperms is a conserved attribute of the plant kingdom. The most prominent phase of the angiosperm life cycle is the sporophytic generation. Sporophytes develop after fertilization of male and female gametes. But gametophyte generation develops after meiosis of spores (Hormaza and Herrero, 1996). These two different generations gives idea for early selection pressure and it can be applied to both male and female gametophytes. It is reported that male gametes are more sensitive for biotic and abiotic stresses so identification of pollen which are more resistance to these stress can be produce more resistant crop plants. And, competition between the large numbers of male gametophytes during development in the anther, pollen germination and tube growth in the style, as well the independent phase that pollen experiences between shedding and stylar deposition, create an opportunity for easier manipulation using the male gametophyte (Ottaviano and Sari Gorla, 1993).

\section{Gamete selection}

Gametophytic selection could be either male or female gametophytic selection. But the male gametes are more susceptible for stress so crop improvement mainly focuses on male gametophytic selection. Male gametophytic development is a very complex process that requires the coordinated participation of various cell and tissue types and their associated specific gene expression patterns. In this process both sporophyitc (anther, tapetum) and gametophytic (pollen) tissues participate in this process. Gametophytic selection is highly reduced system as compared with the sporophyte and therefore it provides opportunities to study the developmental regulation of gene expression and functional interactions between different cell types (Honys et al., 2004).

Male gametophytic selection can occur in two styles: selection for pollen competitive ability or selection for tolerance to environmental stresses. The concept of selecting for pollen competitive ability relies on the assumption that the most vigorous pollen grains will confer vigour to the sporophyte (Ottaviano et al., 1991). The main components of pollen competitive ability are faster pollen germination and pollen tube growth rates which were shown to give rise to positive responses in kernel weight, because germinated pollen which have large pollen tube length can easily fertilize female gametes (Ottaviano et al., 1983). Selective pressure can be most effectively applied at two times: during pollen development or during pollen germination and tube growth (Hormaza and Herrero, 1996). Selection for such traits as herbicide resistance is effective during the quiescent stage, although for many environmental stresses it is important to apply the selection pressure when genetic differences are fully expressed. 


\section{Temperature tolerance in maize}

The global temperature increase day by day and different climate models predict that the global mean temperature will continue this trend, increasing by $1-4^{\circ} \mathrm{C}$ by the end of the twenty-first century, additionally climatological extremes such as heat waves leads to increase temperature more frequently (IPCC, 2013; Tebaldi et al., 2006; Hansen et al., 2015). Above data suggested that average global temperature increases and it also significant different between seasonal and also varies regional that leads to potential impact on the agriculture (IPCC, 2007). Most of the area under maize crop is in the warmer parts of temperate regions and in humid subtropical climate. Highest production is in areas having the temperature $21^{\circ} \mathrm{C}$ to $27^{\circ} \mathrm{C}$. Maize production and productivity are prone to rapid and constant changes due to global warming related environmental changes (Porter, 2005; Wahid et al., 2007). In india also $10-20 \%$ maize yield loss because of temperature fluctuation.

High temperature stresses affects all stages of crop. Among all stages reproductive stage of maize is most sensitive. As the majority of our food supply is a product of sexual reproduction in flowering plants, understanding how different plants cope with stress during their reproductive (gametophytic) phase is critical to managing the future of agricultural productivity. During the short time surrounding fertilization, even a single hot day cause fatal to reproductive success for many plant species. Thus, it is important to consider what aspects of plant sexual reproduction may become the weak links in agricultural productivity. High temperature affect at vegetative as well as reproductive stages of maize.

At temperatures above $38^{\circ} \mathrm{C}$ (reproductive stage), poor seed set in maize has been attributed to both a direct effect of high temperature (Carberry et al., 1989) and pollen desiccation (Schoper et al., 1986; Lonnquist and Jugenheimer, 1943). High temperature affects pollen fertility directly, since the crop showed no visible symptoms of water stress (Schoper et al., 1987).

Pollination is critical process for corn seed set and yield. For kernels to develop, silks must emerge and be fertilized by viable pollen. Silks grow about 1 to 1.5 inches per day and will continue to elongate until fertilized. Temperatures greater than $35^{\circ} \mathrm{C}$ with low relative humidity will desiccate exposed silks, but not greater on impact silk elongation rates greatly. Pollen is no longer viable once temperatures reach the more than optimum, especially with low relative humidity. Fortunately, pollen shed usually occurs from early to mid-morning when temperatures are lower.

The temperature stress induces slow desiccation of silks and result in low seeds set. Historically, this has been the most important problem leading to yield reduction, particularly in stressful years. Once silks begin to desiccate, they lose their capacity for pollen tube growth and fertilization (Madhiyazhagan Ramados et al., 2005). Heat also affects pollen production and viability. First, temperature more than $35^{\circ} \mathrm{C}$ depresses pollen production. Even continuous heat, over several days before and during pollen-shed, results in only a fraction of fertile pollen being formed, probably because of the reduced sugar available. In addition, high temperature reduces the period of pollen viability to a couple hours (or even less). While, there is normally a surplus of pollen, heat can reduce the fertility and amount available for fertilization of silks. It's been also showed that exposure to high temperature reduce the pollen shedding and fertility (Tom Hoegemeyer, 2011). 
There are also plenty of report which showed that high temperature affects at seedling, photosynthesis and even all metabolic of crop plants.

\section{Approaches to crop improvement for heat} stress tolerance

As photosynthesis and reproductive developments are two very sensitive physiological processes for heat stress (Prasad et al., 2008). So screening of genotypes which are resistance on these stages, they are also heat tolerance. There are many approaches available for improvement of heat stress. But there is lack of comprehensive screening methods for heat tolerance and screening at field level is very difficult because fluctuation of temperature in field condition. So need to develop methods by which we can screen the crops at control condition.

During the last few years, interest has been generated in the gametophytic selection/response and it act as an important alternate technique involving for crop improvement. Many researchers examined the possibility of increasing the efficiency of plant breeding through the selection of pollen (Ottaviano et al., 1990; Hormaza and Herrero, 1992).

In vitro screening of pollen grains for temperature tolerance on of effective strategy for selection of plants because high temperature leads to decrease in pollen germination and pollen tube growth and it is also demonstrated in many crops.

Associations between gametophyte and sporophyte have been reported for tolerance to several environmental factors (Ravikumar and Patil, 2004; Clarke et al., 2004). One important area in which pollen response may parallel to that of sporophyte is its response to biotic and abiotic stress factors. Indirect evidence is obtained through an analysis of the behaviour of gametophytic and sporophytic phases in relation to different biotic and abiotic agents.

Variety of selection pressures such as temperature (Zamir et al., 1982; Clark et al., 2004; Dominguez et al., 2005), pathotoxin (Laughnan and Gabay, 1973), herbicide (Sari Gorla, 1989), metal (Searcy and Mulcahy, 1985) and water stress (Ravikumar et al., 2003) were enforced during gametophytic generation and were found very effective in increasing the frequency of resistant individual in the progeny. These studied support that gametophytic selection is potential method which could alternative approach of sporophytic selection.

\section{Gametophytic selection for high temperature tolerance}

Pollen screening is an effective technique of screening the genotypes of crop plants for various stresses. It has been shown that gametophytic (haploid) and sporophytic phase (diploid) do share a common gene expression profile (Mulcahy et al., 1996; Hormaza and Herraro, 1986; Ravikumar et al., 2003). Selection pressure enforced at gametophytic stage improves sporophytic performance.

Maize is susceptible for high temperature and its susceptibility depends on stage of crops. Among all stages, tasseling stage is most susceptible stage for temperature. Temperature is more than ambient at tasseling stage leads to zero seed set at severe condition. There are several attempt have been done to identify heat tolerant genotype at pollen stage.

Pollen grains are simple structured plant cells. Pollen tube formation is a good and simple model of growth and development (Taylor and Hepler, 1997). 
Table.1 Composition of different pollen germination media

\begin{tabular}{|c|c|}
\hline Composition & Reference \\
\hline $\begin{array}{l}5 \% \text { sucrose, } 0.0025 \% \text { boric acid, } 0.056 \% \text { calcium } \\
\text { chloride, } 0.025 \% \text { potassium dihydrogen phosphate, } 3 \% \\
\text { PEG } 4000\end{array}$ & Herrero and Johnson (1980) \\
\hline $\begin{array}{l}\text { Sucrose } 15 \%, 0.6 \% \text { bactoagar, } 0.03 \% \text { calcium nitrate, } \\
0.01 \% \text { boric acid }\end{array}$ & Pfahler and Linskens (1981) \\
\hline $\begin{array}{l}10 \% \text { Sucrose, } 0.6 \% \text { Agar, } 0.03 \text { Boric acid, } 0.05 \% \mathrm{CaCl}_{2} \text {, } \\
0.01 \% \mathrm{MgSO}_{4}\end{array}$ & Shivanna et al., (1991) \\
\hline $\begin{array}{l}\text { Sucrose } 150 \mathrm{~g} / \mathrm{L} \text {, boric acid } 200 \mathrm{mg} / \mathrm{L} \text {, potassium } \\
\text { nitrate } 200 \mathrm{mg} / \mathrm{L}, \quad \text { calcium nitrate } 200 \quad \mathrm{mg} / \mathrm{L} \text {, } \\
\text { magnesium sulphate } 200 \mathrm{mg} / \mathrm{L}, \text { PEG } 223.6 \mathrm{~g} / \mathrm{L}\end{array}$ & Reddy et al.,(2001) \\
\hline $10 \%$ sucrose, $0.7 \%$ agar and 100 ppm IAA & Geetha et al., (2004) \\
\hline $\begin{array}{l}1 \% \text { agarose, } 25 \% \text { sucrose, } 0.52 \mathrm{mM} \mathrm{KNO}_{3}, 3.06 \mathrm{mM} \\
\mathrm{MnSO}_{4}, 1.66 \mathrm{mM} \mathrm{H}_{3} \mathrm{BO}_{3}, 0.42 \mathrm{mM} \mathrm{MgSO}{ }_{4} 7 \mathrm{H}_{2} \mathrm{O} \text { and } 1 \\
\mu \mathrm{M} \text { of gibberellic acid }\end{array}$ & Prabhu and shankar, (2005) \\
\hline $\begin{array}{l}\text { Sucrose } 18 \%, 0.72 \% \text { bactoagar, } 0.036 \% \text { calcium } \\
\text { nitrate, } 0.012 \% \text { boric acid }\end{array}$ & Singh et al., (2016) \\
\hline
\end{tabular}

Fig.1 Life cycle of angiosperm

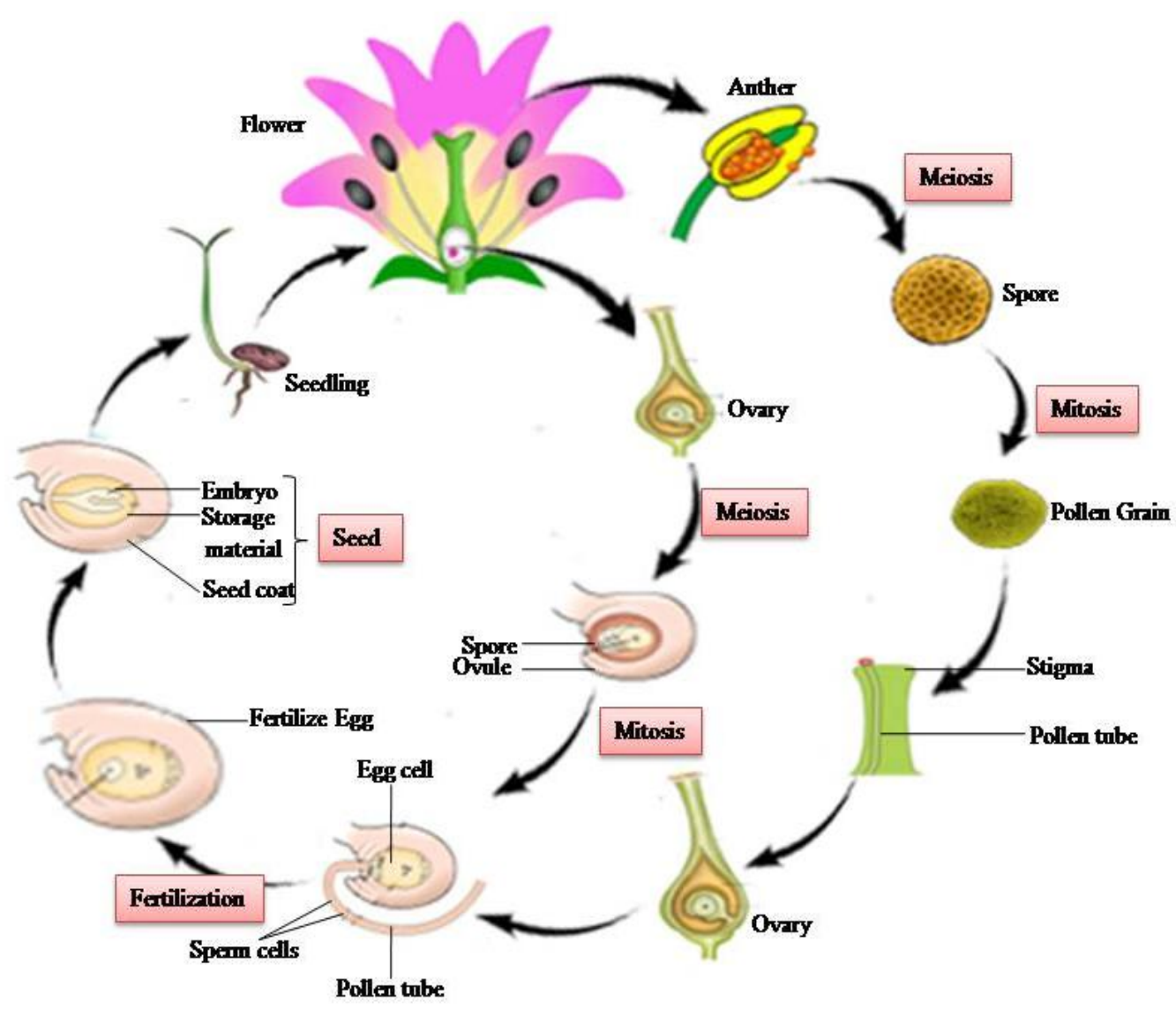


Pollens generally germinate on stigmatic surface of plants (Ünal, 1986). In some plant groups they germinate in anther loculus (Yldrm and Ünal, 1996; Dane, 2000). During the past few years pollen tubes grown under in vitro conditions became a popular model system for cell biology studies in plant cells (Moutinho et al., 2001). The media used for pollen germination vary according to the plant species (Vasil, 1960; Baker and Baker, 1979). Pollens of some species need more complicated media (Çetin et al., 2000). The required environment for pollen germination in vitro is related to genetic composition and also the quality and quantity of nutrient reserves of pollen. There are several media standardized for different crops. There are several media summarized in table 1 .

When high temperature treated pollen exposed in germination media different genotypes respond differently (Geetha et al., 2004 and Singh et al., 2016). These evidences showed that different pollen respond differently at high temperature. The exposure of maize pollen to high temperature $\left(40^{\circ} \mathrm{C}\right)$ reduces the in vitro fertilization percentage, and after 6 hours of stress no fertilization occurs because pollens are susceptible to high temperature (Dupuis and Dumas, 1990).Those genotypes whose pollen germination percentage and large pollen tube length they are resistant for high temperature. The genotypes which showed gametophytic tolerance to heat stress under in vitro conditions produced more number of seeds per cob after heat treatment to pollen grains. A strong correlation exists between pollen and the sporophyte tolerance to various stresses (Herrero and Hormaza, 1996; Ravikumar and Patil, 2004).

\section{References}

Baker, H.B. and Baker, I. Starch in angiosperm pollen grains and; its evolutionary significance. Amer. J. Bot., 66(5): 591-
600, 1979.

Çetin, E., Y>ld $\gg r>m$, C., Palavan-Ünsal, N., and Ünal, M. 2000. Effect of spermine and cyclohexylamine on in vitro pollen germination and tube growth in Helianthus annuus. Can. J. Plant Sci., 80: 241-245.

Clarke, H.J. and K.H.M. Siddique. 2004. Response of chickpea genotypes to low temperature stress during reproductive development. Field Crops Res., 90: 323334

Dom 'inguez, E., Cuartero, J. and Fern'Andezmũnoz, R. 2005. Breeding tomato for pollen tolerance to low temperatures by gametophyticselection. Euphytica, 142: 253-263.

Dupuis, I. and Dumas, C. 1990. Influence of temperature stress on maize (in vitro) fertilization and heat shock protein synthesis in maize (Zea mays L.) reproductive tissue. Plant Physiol., 94: 665-670.

Fehr, W.R. 1991. Principles of cultivar development. Iowa State University: Macmillian Publishing Company, New York. pp. 593.

Geetha, K., Vijayabaskaran, S. and Jayaraman, $\mathrm{N}$. 2004. In vitro studies on pollen germination and pollen tube growth in maize. Food, Agric. Environ., 2(1): 205207.

Herrero, M., and Hormaza, J.I. 1996. Pistil strategies controlling pollen tube growth. Sex. Plant Reprod., 9: 343 - 347

Honys, D. and D. Twell. 2004. Transcriptome analysis of haploid male gametophyte development in Arabidopsis. Genome Biol., 5.

Hormaza, J.I. and M. Herrero. 1996. Male gametophytic selection as a plant breeding tool. Scientia Horticulturae, 65: 321-333.

Hormoza, J.I. and Herrero, M. 1986. Pollen performance as affected by the pistilar genotype in sweet cherry (Prunus avium L.). Protoplasma, 208: 129-135.

Laughnan, J.R. and Gabay, S.J. 1973. Reaction of germinating maize pollen 
Helminthosporium may dispathotoxins. Crop Sci., 13: 681-684.

Mautinho, A., Camacho, L., Haley A., Pais M.S., Trewavas, A., Malho, R. 2001. Antisense perturbation of protein function in living pollen tubes. Sexual Plant Rep., 14: 101-104.

McCormick, S. 2004. Control of male gametophyte development. Plant Cell, 16: S142-S153.

Ottaviano, E. and M. Sari Gorla. 1993. Gametophytic and sporophytic selection. In Plant breeding: Principles and prospects (eds. M.D. Hayward N.O. Bosemark, and I. Romagosa), pp. 332352. Chapman \& Hall, New York.

Ottaviano, E., M.E. Pè, and G. Binelli. 1991. Genetic manipulation of male gametophytic generation in higher plants. In Subcellular Biochemistry: Plant Genetic Engineering (eds. B.B. Biswas and J.R. Harris), pp. 107-142. Plenum Press, New York.

Pfahler, P., and Linskens, H. 1972. In vitro germination and pollen tube growth of maize (Zea mays L.) pollen. Theor. Appl. Genet., 42(3): 136-140.

Prabhu, C.N. and Shankar, R. 2005. Palaeo productivity of the eastern Arabian Sea during the past $200 \mathrm{ka}$ : A multi-proxy investigation. Deep-Sea Res., Part II, 52: pp. 1994-2002.

Ravikumar, R.L. and B.S. Patil. 2004. Effect of gamete selection on segregation of wilt susceptibility-linked DNA marker in chickpea. Curr. Sci., 86: 642-643.

Ravikumar, R.L., Patil, B.S. and Salimath, P.M. 2003. Drought tolerance in sorghum by pollen selection using osmotic stress. Euphytica, 133: 371-376.

Reddy, V.R., Reddy, K.R. and Hodges, H.F.
1991. Temperature effects on growth and development of cotton during the fruiting period. J. Agron., 83: 211-217.

Sari-Gorla, M., M.E. Pe, D.L. Mulcahy, and E. Ottaviano. 1992. Genetic dissection of pollen competitive ability in maize. Heredity, 69: 423-430.

Searcy, K.B. and Mulcahy, D.L. 1990. Pollen selection and gametophytic expression of metal tolerance in Silenedioriaand Mimulus guttatus. Am. J. Bot., 72: 17001706.

Shivanna, K.R., Linskens, H.F. and Cresti, M. 1991. Pollen viability and pollen vigor. Theor. Appl. Genet., 81: 38-42.

Singh, A., Ravikumar, R.L. and P. Jingade. 2016. Genetic Variability For Gametophytic Heat Tolerance In Maize Inbred Lines, Sabrao J. Breeding and Genetics, 48(1): 41-49.

Taylor, L.P. and Hepler, P.K. 1997. Pollen germination and tube growth. Ann. Rev. of Plant Physiol and Plant Mol. Biol., 48: 461-491.

Ünal, M.A. 1986. Comparative cytological study on compatible and incompatible pollen tubes of Petunia hybrid, Ist Univ Fen Fak Mec. Seri B., 51: 1-12.

Vasil, I.K. 1960. Studies on pollen germination of certain Cucurbitaceae. Amer. J. Bot., 47(4): 239-248.

Yldrm, C. and Ünal, M. 1996. Linum hirsitum L. Velinum tenuifolium L. anterlerindepolençimlenmesi. XIII, Ulusal Biyoloji Kongresi, Botanik. Posterleri Kitab., 56: 510-514.

Zamir, D. and I. Gadish. 1987. Pollen selection for low-temperature adaptation in tomato. Theoretical and Appl. Genetics, 74: 545548.

\section{How to cite this article:}

Ashutosh Singh, Rajen Chowdhury and Ratan Das. 2017. Gametophytic Selection: A Simple Technique for Thermo Tolerance Genotypes Identification in Maize. Int.J.Curr.Microbiol.App.Sci. 6(8): 1649-1655. doi: https://doi.org/10.20546/ijcmas.2017.608.198 